\title{
MORTGAGE IN THE RUSSIAN FEDERATION IN JANUARY-MAY 2015
}

\author{
G.Zadonsky
}

Within the first five months of 2015, a decrease in the volume of mortgage housing lending (MHL) as compared to the respective period of 2014 amounted to $38.34 \%$ and $40.96 \%$ in quantitative and monetary terms, respectively. Within the above period, Rb 372,754bn worth of 228,230 MHL was extended. As of 1 June 2015, the outstanding debt on MHL rose by 20.51\% as compared to 1 June 2014 and amounted to Rb 3,586 trillion. In 2015 the share of the overdue debt in the outstanding debt rose as of 1 June to $0.96 \%$ and $15.63 \%$ as regards $M H L$ in rubles and foreign currency, respectively. The weighted average rate on $\mathrm{MHL}$ in rubles extended within a month amounted to 13.46\% in May 2015 having fallen by 1.25 p.p. as compared to the maximum value in February 2015. In 2015 the total number of MHL in foreign currency amounted to 43 loans.

According to the data of the Central Bank of the Russian Federation, within five months of 2015 228,230 mortgage housing loans (MHL) for the total amount of $\mathrm{Rb} 372,754 \mathrm{bn}$ were extended, that is, a decrease of $38.34 \%$ and $40.96 \%$ in quantitative terms and monetary terms, respectively, as compared to the respective period of 2014. In May 2015, $43775 \mathrm{MHL}$ for the total sum of $\mathrm{Rb} 73,765 \mathrm{bn}$ were extended, that is, a decrease of $44.09 \%$ and $45.37 \%$ in quantitative and monetary terms, respectively, as compared to the respective indices of the previous year (Fig. 1). As of 1 June 2015, the outstanding debt on MHL rose by $20.51 \%$ as compared to 1 June 2014 and amounted to $\mathrm{Rb} 3,586$ trillion (Fig. 1).

According to the data of the Central Bank of the Russian Federation, the volume of $\mathrm{MHL}$ in foreign currency ( $R \mathrm{~b} 1,475 \mathrm{bn}$ ) extended from the beginning of the year amounted as of 1 June 2015 to $0.4 \%$ of the total volume of MHL which was a decrease of 0.1 p.p. on the respective period of 2014. Within the same period, the share of the debt on MHL in foreign currency ( $R b$ $112,942 \mathrm{bn}$ ) in the total debt fell by 0.39 p.p. to $3.15 \%$. Within five months of 2015 , the volume of $\mathrm{MHL}$ in foreign currency amounted to $11.97 \%$ and $46.33 \%$ in quantitative terms and monetary terms, respectively as compared to the same period of 2014.

Within five months of 2015, 6335 unsecured housing loans (UHL) were extended, that is, $32.94 \%$ of those extended within the same period of 2014. In monetary terms, the volume of UHL (Rb 8,671bn) amounted to $42.92 \%$ of the volume of the extended UHL in JanuaryMay 2014. Within five months of 2015, the number of UHL amounted to $2.70 \%$ and $2.27 \%$ of the number of the extended housing loans and the volume of housing loans extended within the same period in monetary terms, respectively (Fig. 2). As of 1 June 2015, the outstanding debt on UHL amounted to $\mathrm{Rb} 124,635 \mathrm{bn}$ or $3.36 \%$ of the debt on housing loans, that is, a decrease of 0.39 p.p. as

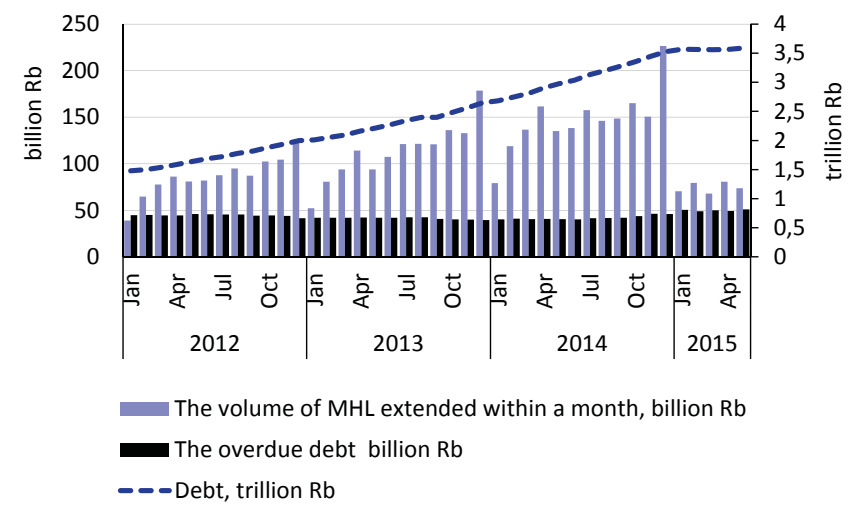

Source: on the basis of the data of the Central Bank of the Russian Federation.

Fig. 1. Dynamics of mortgage housing lending

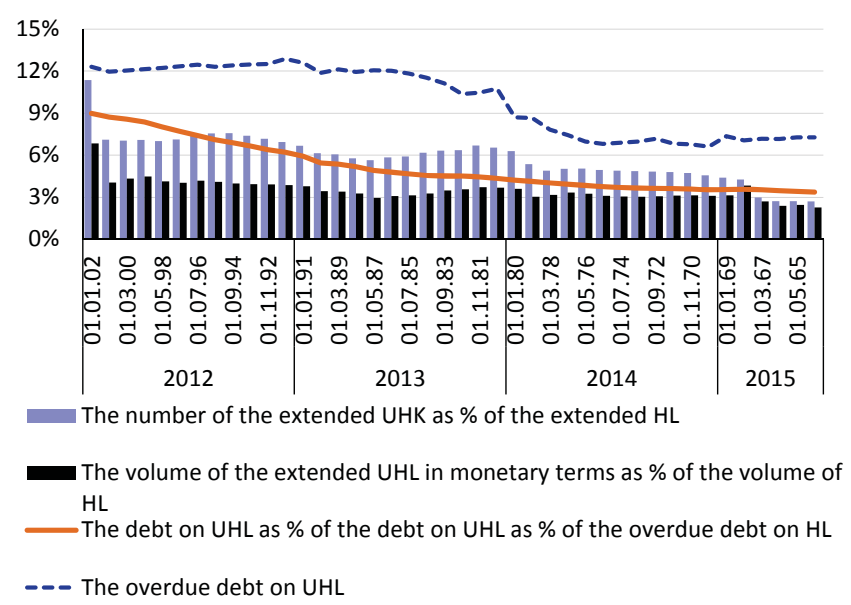

Source: on the basis of the data of the Central Bank of the Russian Federation.

Fig. 2. Dynamics of UHL against HL in general

compared to the data as of 1 June 2014 (Fig. 2). In May, the share of the overdue debt on UHL in the overdue debt on HL remained generally unchanged as compared to April 2015 and amounted to $7.27 \%$ (Fig. 2). 
GROUPING OF THE DEBT ON MHL BY THE PERIOD OF DELAY IN PAYMENTS IN THE 2014-2015

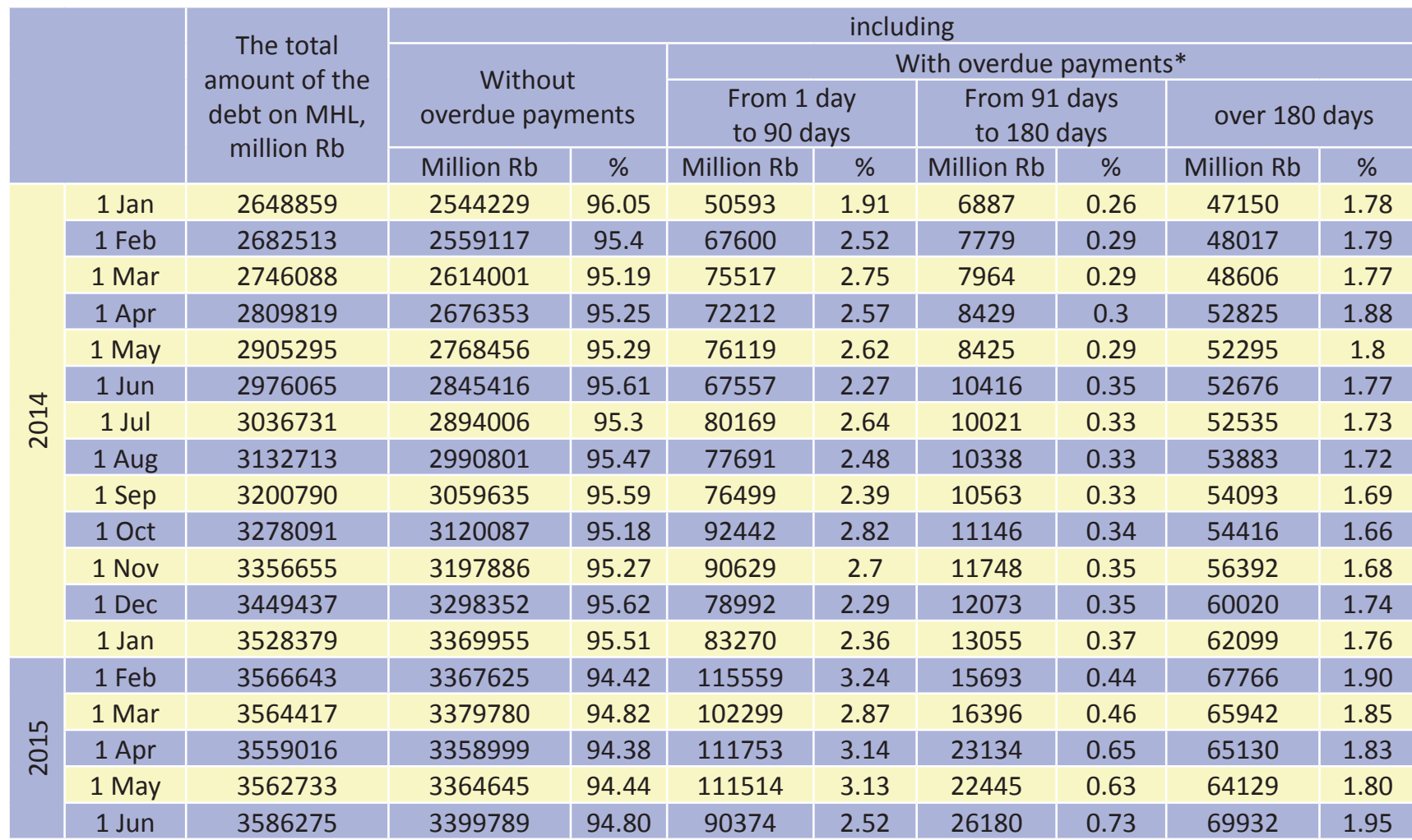

* \% of the total amount of the debt.

Source: the data of the Central Bank of the Russian Federation.

Table 2

DISTRIBUTION OF FEDERAL DISTRICTS BY THE NUMBER OF MHL EXTENDED PER 1000 PERSONS IN 2014 AND 2015

\begin{tabular}{|c|c|c|c|c|c|c|}
\hline \multirow[b]{2}{*}{ Federal district } & \multicolumn{2}{|c|}{ 01.06.2014 per 1000} & \multicolumn{4}{|c|}{ 01.06.2015 per 1000} \\
\hline & $\begin{array}{l}\text { Number, } \\
\text { units }\end{array}$ & $\begin{array}{l}\text { Volume, } \\
\text { million } \mathrm{Rb}\end{array}$ & $\begin{array}{l}\text { Number, } \\
\text { units }\end{array}$ & $\begin{array}{l}\text { Volume, } \\
\text { million } \mathrm{Rb}\end{array}$ & $\begin{array}{l}\text { Debt on } \mathrm{MHL} \text {, } \\
\text { million } \mathrm{Rb}\end{array}$ & $\begin{array}{l}\text { Including the } \\
\text { overdue debt, } \% \text { of } \\
\text { the outstanding debt }\end{array}$ \\
\hline $\begin{array}{l}\text { North-Western } \\
\text { Federal District }\end{array}$ & 3.08 & 5.64 & 2.13 & 3.60 & 29.96 & 1.10 \\
\hline $\begin{array}{l}\text { Privolzhsky Federal } \\
\text { District }\end{array}$ & 3.16 & 4.17 & 1.93 & 2.48 & 22.20 & 0.83 \\
\hline Urals Federal District & 3.01 & 5.25 & 1.92 & 3.06 & 36.78 & 0.92 \\
\hline Siberian Federal District & 2.95 & 4.40 & 1.58 & 2.20 & 25.59 & 1.09 \\
\hline Russian Federation & 2.58 & 4.40 & 1.56 & 2.55 & 24.55 & 1.42 \\
\hline $\begin{array}{l}\text { Far Eastern Federal } \\
\text { District }\end{array}$ & 2.19 & 4.56 & 1.46 & 2.78 & 29.53 & 0.56 \\
\hline Central Federal District & 2.35 & 5.11 & 1.43 & 3.03 & 27.46 & 2.49 \\
\hline Southern Federal District & 2.00 & 3.05 & 1.24 & 1.88 & 17.23 & 1.12 \\
\hline $\begin{array}{l}\text { North-Caucasian } \\
\text { Federal District }\end{array}$ & 0.81 & 1.22 & 0.56 & 0.85 & 7.78 & 1.40 \\
\hline Crimean Federal District & 0.00 & 0.00 & 0.01 & 0.02 & 0.06 & 0.79 \\
\hline
\end{tabular}

Source: on the basis of the data of the Central Bank of the Russian Federation.

As of June 1, 2015, the overdue debt (Fig. 1) on MHL ( $\mathrm{Rb} 50,934 \mathrm{bn}$ ) was $\mathrm{Rb} 10,263 \mathrm{bn}$ or $25.23 \%$ more than the overdue debt as of 1 June 2014. As of 1 June 2015, the share of the overdue debt in the outstanding debt on MHL amounted to $1.42 \%$, which was 0.05 p.p. more than that as of 1 June 2014.
According to the data of the Central Bank of the Russian Federation, as of 1 June 2015 the share of the debt without overdue payments in the total debt on MHL increased by 0.81 p.p. as compared to 1 June 2014 , having amounted to $94.80 \%$; it is to be noted that as of 1 June 2015 the share of the debt on MHL 
Table 3

DISTRIBUTION OF REGIONS OF THE RF BY THE NUMBER OF MHL EXTENDED PER 1,000 PERSONS IN 2015 (12 REGIONS WITH THE LARGEST NUMBER OF MHL PER 1,000 PERSONS)

\begin{tabular}{|c|c|c|c|c|c|c|}
\hline \multirow[b]{2}{*}{ Region of the RF } & \multicolumn{2}{|c|}{ 01.06.2014 per 1000} & \multicolumn{4}{|c|}{ 01.06.2015 per 1000} \\
\hline & $\begin{array}{l}\text { Number, } \\
\text { units }\end{array}$ & $\begin{array}{l}\text { Volume, } \\
\text { million Rb }\end{array}$ & $\begin{array}{l}\text { Number, } \\
\text { units }\end{array}$ & $\begin{array}{l}\text { Volume, } \\
\text { million Rb }\end{array}$ & $\begin{array}{l}\text { Debt on } \mathrm{MHL} \\
\text { million } \mathrm{Rb}\end{array}$ & $\begin{array}{l}\text { Including the } \\
\text { overdue debt as } \% \text { of } \\
\text { the outstanding debt }\end{array}$ \\
\hline Archangelsk Region & 3.30 & 5.07 & 2.61 & 3.89 & 31.11 & 0.46 \\
\hline Magadan Region & 3.38 & 7.58 & 2.59 & 5.50 & 41.47 & 0.11 \\
\hline Republic of Tatarstan & 3.66 & 4.69 & 2.56 & 3.10 & 22.45 & 0.63 \\
\hline Republic of Udmurtia & 4.00 & 4.56 & 2.49 & 2.84 & 25.18 & 0.54 \\
\hline Tyumen Region & 3.79 & 8.44 & 2.45 & 4.97 & 66.35 & 0.44 \\
\hline Ulyanovsk Region & 4.00 & 4.76 & 2.43 & 2.69 & 25.37 & 0.51 \\
\hline Republic of Komi & 4.42 & 7.48 & 2.42 & 3.71 & 35.75 & 0.33 \\
\hline Vologda Region & 3.81 & 4.85 & 2.41 & 2.90 & 27.26 & 0.83 \\
\hline Murmansk Region & 3.31 & 5.47 & 2.39 & 3.92 & 25.88 & 0.46 \\
\hline St. Petersburg & 3.06 & 6.95 & 2.24 & 4.46 & 36.48 & 1.58 \\
\hline Republic of Chuvashia & 3.99 & 5.27 & 2.20 & 2.79 & 27.53 & 0.43 \\
\hline Moscow Region & 2.73 & 7.16 & 2.15 & 5.65 & 43.35 & 2.34 \\
\hline
\end{tabular}

Source: on the basis of the data of the Central bank of the Russian Federation.

with payments overdue for over 180 days (defaulted loans) in the total debt amounted to $1.95 \%$ (Table 1) against $1.77 \%$ as of 1 June 2014 .

In distribution of federal districts by the number of MHL extended per 1,000 persons in January-May 2015, the North-Western Federal District (Table 2) was rated the first with $\mathrm{Rb} 3.6 \mathrm{~m}$ worth of $2.13 \mathrm{MHL}$ per 1,000 persons, that is, $69.25 \%$ and $63.75 \%$ as regards the number and the volume of $\mathrm{MHL}$, respectively, as compared to January-May 2014. The share of overdue payments in the outstanding debt was the smallest one in the Far Eastern District $(0.56 \%)$ and the highest one $(2.49 \%)$ in the Central District (Table 2).

Among the regions, as regards the number and volume of $\mathrm{MHL}$ per 1,000 persons the Archangelsk Region is rated the first $(2.61$ units and $\mathrm{Rb} 3.89 \mathrm{~m}$, respectively) (Table 3), that is, $79.17 \%$ and $76.77 \%$ as regards the number and the volume, respectively, as compared to the respective indices of January-July 2014 (Table 3).

In May 2015, the weighted average period of lending as regards $\mathrm{MHL}$ in rubles extended within a month amounts to 14.3 years which is $0.59 \%$ higher than in April 2015. As regards MHL in foreign currency extended from the beginning of the year, the weighted average period of lending amounted to 3.4 years as of 1 June 2015, having decreased 3.6 times over as compared to 1 June 2014.

In May 2015, the weighted average rate on $\mathrm{MHL}$ in rubles extended within a month fell by 1.25 p.p. to $13.45 \%$ from the maximum value in February; as compared to April it fell by 0.59 p.p. As of 1 June, the weighted average rate on $\mathrm{MHL}$ in rubles extended from the beginning of the year amounted to $14.22 \%$. The weighted rate on MHL in foreign currency extended from the beginning of the year fell within May by 0.83 p.p. and amounted to $10.74 \%$.

On 13 July 2015, the President of the Russian Federation signed the Federal Law on Facilitation of Development and Upgrading of Efficiency of Management in Housing and Amendment of Individual Statutory Acts of the Russian Federation which provides for establishment on the basis of the AHML of a single institute of development in the sphere of housing. The new institute will be entrusted with management functions in respect of the Federal Fund for Facilitation of Housing Development, non-profit organizations established by the single institute of development and subsidiary business entities, including credit institutions.

The OAO AHML signed an agreement with the Gasprombank and the VTB24 bank on cooperation within the frameworks of the state aid program to mortgage borrowers. It is to be noted that the DeltaKredit, the Absolut Bank, the Otkrytie Bank of Khanty-Mansyisk, the Zenit Bank, the LOKO Bank and FORA Bank joined the program.

According to the estimates of the OAO AHML, in January-June 201511 originators fulfilled $\mathrm{Rb} 47,058,827,000$ worth of MHL securitization deals. 